\title{
Igbo Language
}

National Cancer Institute

\section{Source}

National Cancer Institute. Igbo Language. NCI Thesaurus. Code C153955.

A Niger-Congo language of the Ig bo people of southeastern Nigeria. 